\title{
PENGARUH PRILAKU PRODUKTIF DAN TOTAL QUALITY MANAGEMENT TERHADAP KINERJA KARYAWAN (Studi pada TV MU)
}

\author{
Asrul Saptono \\ Program Studi Magister Manajemen Universitas Ahmad Dahlan Yogyakarta \\ Email: rockazruldamn@gmail.com \\ Aftoni Sutanto \\ Program Studi Magister Manajemen Universitas Ahmad Dahlan Yogyakarta \\ Email: aftoni.sutanto@mm.uad.ac.id \\ Abdul Choliq Hidayat \\ Program Studi Magister Manajemen Universitas Ahmad Dahlan Yogyakarta \\ Email: hacholiqh@gmail.com
}

DOI: http://dx.doi.org/10.35908/jeg.v5i1.862

\begin{abstract}
Several factors are used to measure employee performance, namely employee internal factors and external factors that are following an employee's personal needs. One internal factor used to measure employee performance is one of the individual productivity factors and one of the external factors of employees who implement Total Quality Management (TQM) in the company where they work. This study aims to test the success and TQM on employee performance. The object of this research is in the Muhammadiyah Television company in Jakarta and Yogyakarta. Through examining the perception of 30 employees. The method of analysis uses multiple regression.

The results of this study explain that the Productive Behavior Variable has a significant effect on Employee Performance with a significance value of 0.041 less than the Alpha value of 0.05; thus, the first hypothesis accepted. TQM variable is significant on company performance with a significance value of 0,000 smaller than the Alpha value of 0.05. Therefore the second hypothesis is accepted. Hypothesis test results three explain together Productive behavior variables, and TQM significantly influences Employee Performance with a significance value of 0,000 smaller than the Alpha value of 0.05. Thus the null hypothesis is accepted.
\end{abstract}

Keywords : Productive behavior, TQM, Performance.

\begin{abstract}
ABSTRAK
Beberapa faktor yang digunakan untuk mengukur kinerja karyawan, yaitu faktor internal pribadi karyawan dan faktor eksternal yang berada di luar kondisi pribadi karyawan. Salah satu faktor internal yang digunakan untuk mengukur kinerja karyawan adalah perilaku produktif pribadi karyawan dan salah satu faktor eksternal dari pribadi karyawan adalah implementasi Total Quality Management (TQM) pada perusahaan ditempat karyawan bekerja. Tujuan penelitian ini adalah untuk menguji pengaruh Perilaku produktif dan TQM terhadap kinerja karyawan. Lokasi penelitian ini pada perusahaan Televisi Muhammadiyah di Jakarta dan Yogyakarta. Jumlah sampel dalam penelitian ini sebanyak 30 karyawan. Metode analisis menggunakan regresi berganda.

Hasil penelitian ini menjelaskan bahwa Variabel Perilaku Produktif berpengaruh signifikan terhadap Kinerja Karyawan dengan nilai signifikansi sebesar 0,041 lebih kecil dari nilai Alpha 0,05, dengan demikian hipotesis pertama di terima. Variabel TQM berpengaruh signifikan terhadap kinerja karyawan dengan nilai signifikansi sebesar 0,000 lebih kecil dari nilai Alpha 0,05, dengan demikian hipotesis kedua di terima. Hasil uji hipoetsis ketiga menjelaskan bahwa secara bersama-sama variabel Perilaku Produktif dan TQM berpengaruh signifikan terhadap Kinerja Karyawan dengan nilai signifikansi sebesar 0,000 lebih kecil dari nilai Alpha 0,05, dengan demikian hipotesis ketiga di terima.
\end{abstract}

Kata kunci: Perilaku produktif, TQM, Kinerja Karyawan. 


\section{Pendahuluan}

Industri televisi merupakan industri yang terus berkembang pesat seperti di negara Amerika Serikat, Inggris, Australia, Jepang, India dan Qatar. Seperti di negara negara maju lainnya, perkembangan industri televisi di Indonesia juga berkembang pesat terlebih dengan hadirnya platform digital, sehingga semakin banyak investor atau pengusaha yang mencoba berbisnis di dunia pertelevisian. Dengan banyaknya stasiun televisi yang berdiri, semakin banyak pula tenaga kerja yang akan terserap. Sebelumnya, pada siaran analog hanya ada belasan stasiun televisi nasional dan puluhan stasiun televisi lokal. Dengan hadirnya platform digital, ratusan stasiun televisi saat ini sudah berdiri dan semakin banyak lagi pada masa yang akan datang.

Pada sisi sumberdaya manusia, kinerja karyawan tentunya menjadi salah satu faktor yang perlu diperhatikan. Semakin baik kinerja karyawan, maka dapat meningkatkan kinerja perusahaan secara utuh. Kinerja merupakan tingkat pencapaian hasil pada tugas-tugas tertentu yang telah terlaksana. Sedangkan kinerja perusahaan merupakan hasil pencapaian dalam waktu tertentu dalam rangka mewujudkan tujuan perusahaan. Manajemen kinerja merupakan keseluruhan kegiatan yang dilakukan untuk meningkatkan kinerja perusahaan atau organisasi, dalam hal ini termasuk kinerja masing-masing individu dan kelompok kerja pada perusahaan. Upaya untuk meningkatkan kinerja karyawan terdapat beberapa faktor pendukung diantaranya perilaku produktif. Pengelolaan sumber daya manusia (SDM) yang baik akan mengarahkan karyawannya kearah yang produktif. Adapun ciri ciri perilaku produktif yang mengarah kepada peningkatan produktivitas meliputi : (1). Cerdas dan dapat belajar dengan relative cepat, (2). Kompeten secara professional, (3). Kreatif dan inovatif, (4). Memahami pekerjaan, (5). Belajar dengan cerdik menggunakan logika, tidak mudah macet dalam pekerjaan, (6).Selalu mencari perbaikan-perbaikan, tetapi tahu kapan harus berhenti, (7). Dianggap bernilai oleh atasannya, (8). Memiliki catatan prestasi yang baik, dan (9). Selalu meningkatkan diri. Perilaku produktif dapat ditingkatkan dengan menggunakan total quality manajemen, dengan adanya kualitas sumber daya manusia yang baik maka dapat menghasilkan kinerja karyawan yang tinggi sehingga menghasilkan produk yang berkualitas pula. Tidak hanya itu, ketersediaan produk dapat terjaga sehingga daya saing perusahaan pun meningkat dan pada akhirnya perusahaan dapat bertahan terlebih menjadi pemenang kompetisi atau persaingan (Simanjuntak, 2005).

Banyaknya perusahaan pertelevisian maka dapat dipastikan persaingan menjadi semakin ketat. Perusahaan yang memiliki daya sainglah yang akan bertahan. Guna memperoleh daya saing maka diperlukan kualitas baik pada sisi manajemen maupun sumberdaya manusia. Kualitas menjadi hal utama yang menjadi titik fokus setiap perusahaan. Berbagai hal dilakukan untuk meningkatkan kualitas yang diterapkan pada produk, pelayanan dan manajemen perusahaan. Seiring dengan perkembangan ilmu pengetahuan, lahirlah suatu inovasi yang dikenal dengan TQM. Total quality management merupakan suatu pendekatan dalam menjalankan usaha yang mencoba untuk memaksimumkan daya saing organisasi melalui perbaikan terusmenerus atas produk, jasa, manusia, proses, dan lingkungannya (Tjiptono dan Diana 2003). Total quality management 
adalah perpaduan semua fungsi manajemen, semua bagian dari perusahaan, dan semua orang kedalam falsafah holistic yang dibangun berdasarkan konsep kualitas, teamwork, produktivitas dan kepuasan konsumen (Nasution, 2005)

Salah satu stasiun televisi di Indonesia adalah PT Tvmu Surya Utama atau lebih dikenal sebagai Televisi Muhammadiyah (TV Mu). TV Mu merupakan Lembaga Penyiaran Swasta Penyelenggara Penyiaran Televisi yang mengambil peran sebagai medium sumber informasi, pendidikan, dakwah dan kontrol sosial, yang diharapkan mampu menjadi inspirasi, referensi dan motivasi bagi khalayak umat guna meningkatkan harkat, martabat dan kualitas kehidupan. Sebagai medium dakwah dalam konteks luas, TVMu akan mengambil peran aktif bagi upaya perbaikan kualitas kehidupan bangsa dan manusia secara universal, melalui isi siaran yang bermutu, mencerdaskan, mencerahkan, membentuk watak yang berbudi pekerti luhur. Televisi Muhammadiyah lahir pada November 2013 dan berpusat di Jakarta. Jenis kelamin dari Televisi Muhammadiyah adalah televisi dakwah, syiar Islam dibawah naungan Pimpinan Pusat Muhammadiyah.

Permasalahan yang dihadapi menjelaskan bahwa perjalanan televisi Muhammadiyah belum berjalan maksimal seperti yang diharapkan, banyak kendala baik dalam bidang operasional, finansial, marketing, maupun sumber daya manusia. Produktivitas pada televisi Muhammadiyah pun, belum semaksimal yang diharapkan. Hal ini terlihat dari masih banyaknya siaran ulang (rerun) pada pola siar Televisi Muhammadiyah. Belakangan ini banyak stasiun televisi yang berdiri, maka suatu perusahaan harus memiliki strategi untuk dapat tetap produktif dan bersaing. Kemudian, bagaimana kepemimpinan dalam suatu perusahaan yang menjadi ujung tombak dalam eksistensi, serta kinerja karyawan yang ada menjadi faktor pendukung dalam suatu perusahaan untuk tetap produktif menjadi suatu hal yang menarik untuk dikaji.

Penelitian ini ingin melihat lebih jauh mengenai pengaruh perilaku produktif terhadap kinerja karyawan, selain itu juga akan mengukur total quality management terhadap kinerja karyawan pada Televisi Muhammadiyah. Maka permasalahan yang akan dijawab dalam penelitian ini, yaitu apakah perilaku produktif berpengaruh signifikan terhadap kinerja karyawan pada televisi Muhammadiyah? Apakah total quality management berpengaruh signifikan terhadap kinerja karyawan pada televisi Muhammadiyah? apakah perilaku produktif dan total quality management secara simultan berpengaruh signifikan terhadap kinerja karyawan pada televisi Muhammadiyah? Sedangkan tujuan yang akan dicapai dalam penelitian ini adalah untuk menguji dan menganalisis variabel perilaku produktif dan TQM berpengaruh terhadap kinerja karyawan.

Sumber Daya Manusia (SDM) merupakan salah satu aset perusahaan atau organisiasi bisnis maupun non bisnis. Kemajuan perusahaan sangat tergantung oleh kinerja karyawan atau SDM yang dimilikinya, (Indrasari (2017). Semakin baik kinerja karyawan maka tujuan perusahaan atau organisasi dapat tercapai sesuai dengan target yang telah ditentukan sebelumnya. Sebaliknya apabila kinerja karyawan tidak dikelola dengan baik, maka resiko yang akan ditanggung oleh perusahaan semakin besar. Pegelolaan kinerja tidak sebatas pada alat untuk 
mengevaluasi kinerja karyawan tetapi sebagai strategi untuk menilai dan memotivasi perningkatan produktivitas kerja (Pratama dan Maghfiroh, 2016).

Kinerja diartikan sebagai hasil usaha seseorang yang dicapai dengan kemampuan dan perbuatan dalam situasi tertentu. Kinerja telah menjadi terminologi atau konsep penting dalam berbagai pembahasan khususnya dalam mendorong keberhasilan organisasi dan sumber daya manusia. Kinerja akan selalu menjadi isu aktual dalam organisasi karena apapun organisasinya kinerja merupakan kunci terhadap efektifitas keberhasilan organisasi. Organisasi yang efektif atau berhasil akan di topang oleh sumber daya manusia yang berkualitas (Pratama dan Maghfiroh, 2016).

Kinerja merupakan seperangkat hasil yang dicapai serta merujuk pada tindakan pencapaian serta pelaksanaan sesuatu pekerjaan yang diminta. Kinerja diartikan sebagai hasil usaha seseorang yang dicapai dengan kemampuan dan perbuatan dalam situasi tertentu. Kinerja yang dicapai oleh individu pekerja sangat dipengaruhi oleh faktor internal dan eksternal dari individu tersebut yang apa bila dirinci merupakan faktor-faktor yang sangat kompleks (Pratama dan Maghfiroh, 2016).

Konsep produktivitas telah berkembang selama bertahun-tahun untuk mewakili lebih dari rasio efisiensi. Dari masalah biaya dan kualitas, itu ruang lingkup telah diperluas untuk mencakup masalah sosial seperti pekerjaan. penciptaan, keamanan pekerjaan, pengentasan kemiskinan, konservasi sumber daya, tanggung jawab sosial untuk keunggulan bisnis, tata kelola, dan perlindungan lingkungan (Green Productivity). Saat ini, konsep produktivitas lain yang telah berkembang termasuk produktivitas sosial dan produktivitas pengetahuan (Wiandari dan Darma, 2017).

Produktivitas kerja adalah kemampuan karyawan dalam berproduksi dibandingkan dengan input yang digunakan, seorang karyawan dapat dikatakan produktif apabila mampu menghasilkan barang atau jasa sesuai dengan harapan dalam waktu yang singkat atau tepat. Perilaku produktivitas sudah menjadi perhatian yang sangat besar karena ada pemikiran bahwa sebenarnya produktivitas manapun bersumber dari individu yang bersangkutan, namun individu yang dimaksud adalah individu sebagai tenaga kerja atau karyawan pada suatu perusahaan atau organisasi yang memiliki perilaku kerja produktif sehingga dapat menghasilkan kualitas kerja yang memadai.

Indikator perilaku produktif yang dikembangkan dan dimodifikasi dari pemikiran yaitu 1) tindakan konstruktif; 2) percaya diri sendiri; 3) bertanggung jawab; 4) memiliki rasa cinta terhadap pekerjaaan; 5) mempunyai pandangan ke depan; 6) mampu mengatasi persoalan dan dapat menyesuaikan diri dengan lingkungan yang berubah-ubah; 7) mempunyai kekuatan positif terhadap lingkungannya dan 8) memiliki kekuatan untuk mewujudkan potensinya (Damayanti dan Cahyadi, 2018).

Perilaku produktif yang baik maka kinerja karyawan akan semakin meningkat. Kondisi ini dikuatkan bahwa perilaku produktif karyawan terhadap kinerja karyawan adalah berpengaruh signifikan (Sugiyono, 2014). Dari pernyataan di atas dan penelitian terdahulu maka dapat dirumuskan hipotesis sebagai berikut:

H1: Perilaku produktif berpengaruh signifikan terhadap kinerja karyawan. 
Kualitas menjadi hal utama yang menjadi titik fokus setiap perusahaan. Berbagai hal dilakukan untuk meningkatkan kualitas yang diterapkan pada produk, pelayanan dan manajemen perusahaan. Seiring dengan perkembangan ilmu pengetahuan, lahirlah suatu inovasi yang dikenal dengan TQM. Total quality management merupakan suatu pendekatan dalam menjalankan usaha yang mencoba untuk memaksimumkan daya saing organisasi melalui perbaikan terus-menerus atas produk, jasa, manusia, proses, dan lingkungannya (Tjiptono dan Diana, 2003).

Total quality management adalah perpaduan semua fungsi manajemen, semua bagian dari perusahaan, dan semua orang kedalam falsafah holistic yang dibangun berdasarkan konsep kualitas, teamwork, produktivitas dan kepuasan konsumen. Dalam penerapan TQM, ada 10 unsur utama yang dikembangkan sebagai berikut (Tjiptono dan Diana, 2003):

Fokus pada pelanggan

Dalam TQM, baik pelanggan internal maupun pelanggan eksternal merupakan penggerak. Pelanggan eksternal menentukan kualitas produk atau jasa yang disampaikan kepada mereka, sedangkan pelanggan internal berperan besar dalam menentukan kualitas tenaga kerja, proses, dan lingkungan yang berhubungan dengan produk atau jasa.

\section{Obsesi terhadap kualitas}

Dengan adanya kualitas yang telah ditetapkan, organisasi harus terobsesi untuk memenuhi atau melebihi apa yang telah ditentukan sebelumnya. Hal ini berarti bahwa semua karyawan pada tiap level berusaha melaksanakan setiap aspek pekerjaannya berdasarkan perspektif untuk melakukan segala sesuatunya dengan lebih baik.

Pendekatan Ilmiah

Pendekatan ilmiah diperlukan dalam penerapan TQM, terutama untuk mendesain pekerjaan dan dalam proses pengambilan keputusan dan pemecahan masalah yang berkaitan dengan pekerjaan yang didesain tersebut.

\section{Komitmen Jangka Panjang}

TQM merupakan suatu paradigma baru dalam melaksanakan bisnis. Untuk itu, dibutuhkan budaya perusahaan yang baru pula. Oleh karena itu, komitmen jangka panjang sangat penting guna mengadakan perubahan budaya agar penerapan TQM dapat berjalan dengan sukses.

\section{Kerjasama tim ( Teamwork)}

Dalam organisasi yang menerapkan TQM, kerjasama tim, kemitraan dan hubungan dijalin dan dibina, baik antar karyawan perusahaan maupun dengan pemasok, lembaga-lembaga pemerintahan, dan masyarakat sekitarnya.

Perbaikan sistem secara berkesinambungan (continuous improvement)

Setiap produk atau jasa dihasilkan dengan memanfaatkan proses-proses tertentu di dalam suatu sistem / lingkungan. Oleh karena itu, sistem yang ada perlu diperbaiki secara terus-menerus agar kualitas yang dihasilkannya dapat semakin meningkat.

Pendidikan dan pelatihan

Dalam menerapkan TQM, pendidikan dan pelatihan merupakan faktor yang fundamental untuk dapat berkembang dan bersaing dengan perusahaan lain, apalagi dalam era persaingan global. 
Kebebasan yang terkendali

Kebebasan yang timbul karena keterlibatan dan pemberdayaan karyawan merupakan hasil dari pengendalian yang terencana dan terlaksana dengan baik.

\section{Kesatuan tujuan}

Agar TQM dapat diterapkan dengan baik, maka perusahaan harus memiliki kesatuan tujuan. Dengan demikian, setiap usaha dapat diarahkan pada tujuan yang sama.

Adanya keterlibatan dan pemberdayaan karyawan

Keterlibatan dan pemberdayaan karyawan merupakan hal yang penting dalam penerapan TQM. Tujuan pelibatan dan pemberdayaan adalah untuk meningkatkan kemampuan organisasi untuk memberikan customer value. Total Quality Management adalah perpaduan semua fungsi manajemen, semua bagian dari perusahaan, dan semua orang kedalam metode yang dibangun berdasarkan konsep kualitas, teamwork, dan kepuasan konsumen. dengan adanya Total Quality Management yang baik maka akan meningkatkan kinerja karyawan (Simanjuntak, 2005)

Berdasarkan hasil pengujian data melalui path analysis menjelaskan bahwa TQM berpengaruh secara signifikan dan positif terhadap kinerja karyawan dengan nilai $\mathrm{t}$ hitung sebesar 16,8728 dan nilai koefisien jalur sebesar 0,772 (Kalaw, 2015). Hal ini dijelaskan bahwa TQM berpengaruh positif dan signifikan terhadap kinerja karyawan (Sedarmayanti, 2001). Berdasarkan kajian pustaka diatas dan penelitian terdahulu maka dapat dirumuskan hipotesis sebagai berikut:
H2: TQM berpengaruh signifikan terhadap kinerja karyawan.

H3: Perilaku Produktif dan TQM secara simultan berpengaruh signifikan terhadap kinerja karyawan

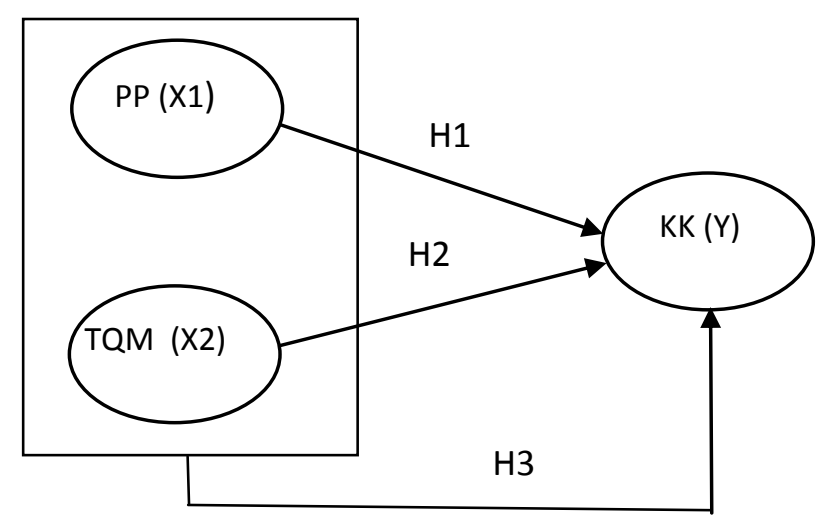

Gambar. 1. Model Penilitian

Sumber: Model Penelitian diolah

Keterangan :

PP = Perilaku Produktif

$\mathrm{TQM}=$ Total Quality Management

KK = Kinerja Karyawan

\section{Metode Penelitian}

Penelitian ini dilakukan menggunakan metode penelitian kuantitatif. Objek penelitian ini adalah PT. TVMU Surya Utama yang berkantor pusat di Jakarta dan kantor pembantu di Yogyakarta. Populasi pada penelitian ini berjumlah 34 karyawan. Sampel penelitian ini menggunakan seluruh anggota populasi pada PT. TVMU Surya Utama. Teknik pengambilan sampling menggunakan metode sensus atau sampel jenuh. Responden dalam penelitian ini adalah seluruh karyawan PT. TVMU Surya Utama, atau yang lebih dikenal dengan Televisi Muhammadiyah. Teknik pengumpulan data dalam penelitian ini dilakukan dengan menyebarkan kuesioner kepada seluruh responden. Instrumen survei menggunakan skala likert lima poin di mana 1 menunjukkan paling 
rendah, 2 rendah, 3 rata-rata, 4, tinggi dan 5 menunjukan paling tinggi (Sugiyono, 2014).

$$
\text { Uji validitas menggunakan }
$$

Confirmatory Factor Analisys (CFA). Instrumen dikatakan valid jika membentu 1 (satu) komponen. Pengujian reliabilitas menggunakan Crobach's Coefficient Alpha dengan ukuran multi-item memiliki nilai alpha di atas 0,60. Metode analisis yang digunakan dalam penelitian ini adalah analisis regresi linear berganda untuk melihat pengaruh variable bebas terhadap variable terikat (Sugiyono, 2014).

\section{Pembahasan}

Pembahasan hasil penelitian diawali dengan penjelasan metode pengumpulan data, yaitu dengan menyebarkan kuesioner kepada seluruh anggota populasi berjumlah 34 karyawan pada bulan Agustus sampai September 2019. Jumlah kuesioner yang memenuhi persyaratan untuk di analisis sebanyak 30 kuesioner, sedangkan 1 (satu) kuesioner tidak lengkap dalam pengisian dan 3 (tiga) kuesioner tidak kembali. Selanjutnya dilakukan uji validitas dan reliabilitas. Hasil uji validitas terdapat 1 (satu) butir pernyataan yang tidak valid pada variabel Kinerja Karyawan (Y), yaitu butir pernyataan nomor (Y2), selanjutnya butir pernyataan yang tidak valid pada variabel Perilaku Produktif (X1), yaitu butir pernyataan nomor (X16), sedangkan pada variabel TQM semua dinyatakan valid karena sudah membentuk 1 (satu) komponen. Dengan demikian butir pernyataan yang tidak valid tersebut dikeluarkan dari daftar pernayataan dari masing-masing variabel dan dilakukan uji lagi, hasil uji yang sudah valid seperti pada Tabel 1 berikut ini.
Tabel I

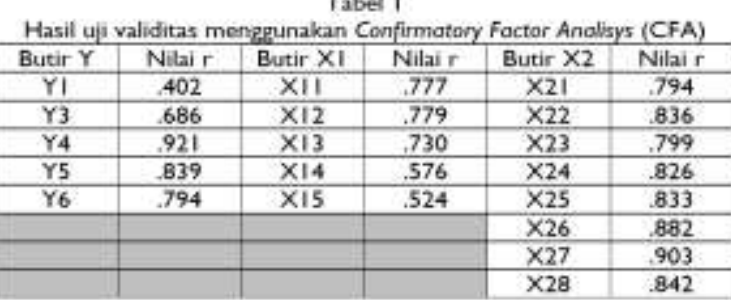

Sumber data diolah 2019

Hasil uji validitas pada Tabel 1 dijelaskan bahwa butir pernyataan yang valid untuk variabel Kinerja Karyawan (Y) sebanyak 5 (lima) butir pernyataan, sedangkan butir pernyataan nomor Y2 di keluarkan dari daftar kuesioner sehingga membentuk 1 (satu) komponen. Hasil uji validitas untuk Variabel Prilaku Produktif (X1) sebanyak 5 butir pernyataan, sedangkan butir pernyataan X16 dikeluarkan dari daftar kuesioner sehingga membentuk satu komponen. Selanjutnya hasil uji validitas untuk variabel TQM (X2) sebanyak 8 (delapan) butir pernyataan, semua dinyatakan valid karena sudah membentuk satu komponen. Setelah semua bitur pernyataan dinyatakan lolos uji validitas kemudian dilajutkan tahap berikutnya, yaitu uji reliabilitas dan hasil uji reliabilitas seperti pada Tabel 2 berikut ini.

Tabel 2. Hasil Ui Reliabilicas

\begin{tabular}{|c|c|c|c|}
\hline Variabel & $\begin{array}{c}\text { Cronbach's } \\
\text { Alpha }\end{array}$ & $\mathrm{N}$ of Item & Keterangan \\
\hline $\mathrm{Y}$ & .790 & 5 & Reliabel \\
\hline $\mathrm{X} 1$ & .698 & 5 & Reliabel \\
\hline $\mathrm{X} 2$ & .939 & 8 & Reliabel \\
\hline
\end{tabular}

Sumber data diolah 2019

Hasil uji reliabilitas pada Tabel 2 dijelaskan bahwa semua variabel memperoleh nilai Cronbach's Alpha di atas 0,60. Artinya bahwa semua butir pernyataan masing-masing variabel memiliki tingkat kehandalan yang tinggi. Dengan demikian kuesioner yang berhasil dikumpulkan sudah memenuhi persyaratan 
uji validitas dan relibilitas. Berdasarkan hasil uji instrumen tersebut, maka langkah selanjutnya adalah melakukan uji hipotesis baik secara parsial yaitu dengan uji t, maupun secara simultan dengan uji $F$ seperti pada Tabel 3 berikut ini.

Tabel 3.

Hasil Ui Hipotesis Secara Parsial
\begin{tabular}{|l|c|c|c|c|}
\hline \multicolumn{1}{|c|}{ Model } & B & Ui t & Sig & Keterangan \\
\hline (Constanta) & 2.209 & 3.883 & .001 & - \\
\hline Perilaku Produktif $(X 1)$ & -361 & -2.151 & .041 & Signifikan \\
\hline TQM (X2) & .807 & 9.630 & .000 & Signifikan \\
\hline
\end{tabular}
Dependent Variabel: Kinerja Karyawan (Y)

Sumber data diolah 2019

Hasil uji hipotesis secara parsial pada Tabel 3 menjelaskan bahwa semua variabel independen memiliki pengaruh yang signifikan terhadap variabel dependen. Variabel Perilaku Produktif (X1) memperoleh hasil nilai signifikansi sebesar $0,041<$ alpha $(0,05)$, dan nilai koefisien beta sebesar -0,361. Artinya variabel Perilaku Produktif (X1) berpengaruh negatif dan signifikan terhadap Kinerja Karyawan (Y), dengan demikian hipotesis pertama yang menyatakan bahwa variabel Perilaku Produktif berpengaruh signifikan terhadap Kinerja karyawan diterima, walaupun hubungan kedua variabel tersebut memiliki arah yang negatif. Kemudian Variabel TQM (X2) memperoleh nilai signifikansi sebesar $0,000<$ alpha $(0,05)$, dan nilai koefisien beta sebesar 0,807. Artinya bahwa variabel TQM (X2) berpengaruh postitif dan signifikan terhadap kinerja karyawan (Y), dengan demikian hipotesis kedua yang menyatakan bahwa variabel TQM berpengaruh signifikan terhadap Kinerja karyawan diterima.
Tabel 4.

Hasil Uji Hipotesis Secara Simultan

\begin{tabular}{l|r|c|c|c|}
\hline \multicolumn{1}{|c|}{ Model } & Sum of Squares & U $\mathrm{F} F$ & Siq & Keterangan \\
\hline Regression & 10.733 & 59.438 & .000 & Signifikan \\
Residual & 2.438 & & & \\
Totla & 13.171 & & & \\
\hline & Predictors: (Constanta), Perilaku Produktif (X1). TQM (X2) \\
Dependent Variable: Kinerja Karyawan (Y)
\end{tabular}

Sumber data diolah 2019

Hasil uji F pada Tabel 4 dijelaskan bahwa uji hipotesis secara simultan diperoleh nilai signifikansi sebesar $0,000<$ alpha $(0,05)$, artinya bahwa semua variabel independen, yaitu variabel Perilaku Produktif (X1) dan Variabel TQM (X2) secara simultan berpengaruh signifikan terhadap kinerja karyawan (Y), dengan demikian hipotesis yang menyatakan bahwa variabel Perilaku Produktif dan Variabel TQM secara simultan berpengaruh signifikan terhadap kinerja karyawan diterima.

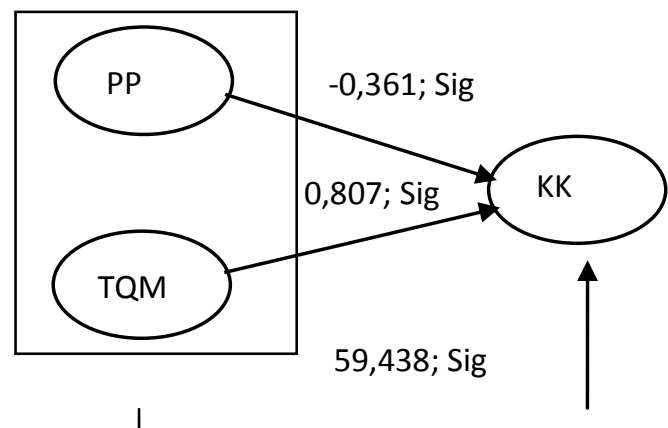

Gambar 2. Hasil Model Penilitian, R Square 0,815

Sumber: Hasil Model Penelitian diolah

Keterangan :

PP $\quad=$ Perilaku Produktif

TQM = Total Quality Management

KK = Kinerja Karyawan

Tabel 5

Hasil Uji Koefisien Regresi berganda

\begin{tabular}{|c|c|c|c|c|}
\hline Model & $R$ & R Square & $\begin{array}{c}\text { Adjusted } \\
\text { R Square }\end{array}$ & $\begin{array}{c}\text { Std. Error of } \\
\text { The Estimate }\end{array}$ \\
\hline Regression & $.903^{\circ}$ & .815 & .801 & .30048 \\
\hline
\end{tabular}

a Predictors: (constanta), Perilaku Produktif, TQM

Sumber data diolah 2019 
Hasil uji koefisien regresi berganda pada Tabel 5 menjelaskan bahwa penelitian yang menguji pengaruh variabel Prilaku produktif (X1) dan variabel TQM (X2) terhadap kinerja karyawan (Y) diperoleh nilai $\mathrm{R}$ Square sebesar 0,815. Artinya bahwa semua variabel independen, yaitu Perilaku produktif (X1) dan variabel TQM (X2) mampu menjelaskan kepada variabel dependen yaitu Kinerja Karyawan (Y) sebesar 81,5\%, sedangkan sisanya sebesar $18.5 \%$ dijelaskan oleh variabel independen yang lainnya diluar model dalam penelitian ini. Model penelitian ini menggunakan dua variabel independen yang mampu membentuk suatu model penelitian yang baik, karena memiliki nilai R square di atas $50 \%$.

Berdasarkan hasil uji regresi berganda diperoleh hasil bahwa semua variabel independen, yaitu variabel perilaku produktif dan TQM secara parsial berpengaruh signifikan terhadap kinerja karyawan. Untuk variabel Perilaku Produktif diperoleh hasil berpengaruh signifikan terhadap kinerja karyawan. Namun kedua variabel ini memiliki hubungan yang negatif atau berlawanan arah. Artinya bahwa jika semakin tinggi perilaku produktif maka kinerja karyawan semakin rendah, atau sebaliknya jika semakin rendah perilaku produktif maka semakin tinggi kinerja karyawan. Hasil olah data dalam penelitian ini memang berbeda dengan beberapa penelitian lainnya, namun demikian temuan ini merupakan temuan baru yang dapat dijelaskan bahwa hasil empiris pada kasus khusus di TVMu memiliki keunikan dan berbeda dengan jenis perusahaan lainnya. Dengan demikian hasil olah statistik ini mengkonfirmasi hasil penelitian yang dilakukan oleh Wiandari dan Darma, (2017) yang menjelaskan bahwa perilaku produktif karyawan terhadap kinerja karyawan adalah berpengaruh signifikan, namun kedua variabel ini memiliki hubungan yang negatif atau berlawanan arah.

Untuk variabel TQM berpengaruh positif terhadap kinerja karyawan. Artinya bahwa semakin baik implementasi TQM pada TVMu akan meningkatkan kinerja karyawan dalam menghasilkan produk. Hasil ini mendukung penelitian yang telah dilakukan oleh Pratama dan Maghfiroh (2016) yang menyakatan bahwa TQM berpengaruh positif dan signifikan terhadap kinerja karyawan. Dengan demikian hipotesis kedua yang menyatakan bahwa TQM berpengaruh signifikan terhadap kinerja karyawan diterima.

Berdasarkan hasil olah data statistik uji $\mathrm{F}$ menunjukan bahwa secara bersamasama variabel perilaku produktif dan TQM berpengaruh positif dan signifikan terhadap kinerja karyawan. Hasil ini sesuai dengan hipotesis yang dirumuskan dalam penelitian ini bahwa secara bersama-sama variabel perilaku produktif dan TQM berpengaruh positif dan signifikan terhadap kinerja karyawan. Hasil tersebut juga dikuatkan oleh uji koefisien regresi berganda dengan nilai $\mathrm{R}$ Square sebesar 0,815 . Artinya bahwa semua variabel independen, yaitu variabel Perilaku produktif dan TQM secara bersama-sama mampu menjelaskan kepada variabel dependen yaitu kinerja karyawan sebesar $81,5 \%$. Selain itu juga dapat dijelaskan bahwa model penelitian ini memiliki uji kelayakan model (goodness of fit) yang baik karena nilai $\mathrm{R}$ square di atas 0,50.

Suatu model penelitian yang digunakan untuk mengukur ketepatan fungsi regresi dalam menaksir nilai aktual (variabel independen terhadap dependen) 
dapat diperoleh dari uji goodness of fit melalui beberapa pengukuran, yaitu: 1) nilai koefisien determinasi, 2) nilai statistik uji F dan 3) nilai statistik uji t. Koefisien determinasi dilakukan untuk mendeteksi ketepatan model yang paling baik dalam analisis regresi, yaitu dengan membandingkan besarnya nilai koefisien determinan, jika $\mathrm{R}$ square semakin besar mendekati 1 (satu) maka model penelitian semakin tepat. Sebaliknya jika nilai $\mathrm{R}$ square semakin kecil mendekati 0 (nol) maka model penelitian semakin terbatas atau tidak tepat (Ghozali, 2016).

\section{Kesimpulan}

Tujuan penelitian ini untuk menguji dan menganalisis variabel perilaku produktif dan TQM berpengaruh signifikan terhadap kinerja karyawan. Berdasarkan hasil analisis dan pembahasan dapat disimpulkan bahwa variabel perilaku produktif berpengaruh signifikan terhadap kinerja karyawan, walaupun kedua variabel tersebut memiliki hubungan yang negatif atau berlawanan arah. Hasil ini merupakan temuan penelitian yang menarik bahwa kasus khusus pada perusahaan TVMu telah terjadi jika perilaku produktif tinggi, maka kinerja karyawan semakin menurun atau sebaliknya. Selanjutnya variabel TQM berpengaruh positif dan signifikan terhadap kinerja karyawan. Semakin baik implementasi TQM pada TVMu akan meningkatkan kinerja karyawan dalam menghasilkan produk. Berdasarkan uji $\mathrm{F}$ menjelaskan bahwa secara bersama-sama ketiga variabel independen berpengaruh positif dan signifikan terhadap variabel dependen.

\section{Daftar Pustaka}

Damayanti, Riski Hanafi Agustina dan Cahyadi, Afriyadi (2018). Pengaruh Kepuasan Kerja Terhadap Kinerja Karyawan (Studi Kasus Karyawan Non Medis Rs Islam Siti Khadijah Palembang). Jurnal Ilmiah Manajemen Bisnis Dan Terapan Tahun XV No 2, Oktober 2018.

Ghozali, Imam. 2016. Aplikasi Analisis Multivariate dengan Program SPSS. Semarang: Badan Penerbit Universitas Diponegoro.

Indrasari, Meithiana, 2017. Kepuasan Kerja dan Kinerja Karyawan, Tinjauan dari dimensi iklim organisasi, krestivitas individu, dan karakteristik pekerjaan. Indomedia Pustaka, Sidoarjo.

Kalaw, Antonio D. 2015. Handbook on Productivity. First published in Japan. Printed by Hirakawa Kogyosha Co., Ltd., Japan

Nasution, M 2005, "Total Quality Management”, PT Gramedia Pustaka Utama: Jakarta

Pratama, Abdul Aziz Nugraha dan Maghfiroh, Fira Nur. (2016). Pengaruh Total Quality Management (TQM) terhadap kinerja karyawan di BMT Taruna Sejahtera Ungaran, Jawa Tengah. Jurnal Muqtasid. Volume 7 Nomor 1.

Sedarmayanti, 2001. Sumber Daya Manusia dan Produktivitas Kerja. Bandung Penerbit Mandar Maju.

Simanjuntak, Payaman J. 2005. Manajemen dan Evaluasi Kinerja. Jakarta: FE UI.

Sugiyono. 2014. Metode Penelitian Pendidikan Pendekatan Kuantitatif, 
Kualitatif Dan $R \& D$. Bandung: Alfabeta.

Tjiptono, Fandy dan Anastasia Diana. (2003). Total Quality Management. Edisi Revisi. Yogyakarta: Andi Offset.

Wiandari, Ida Ayu Andini dan Darma, Gede Sri (2017). Kepemimpinan, Total Quality Manajemen, Perilaku produktif karyawan, Kinerja karyawan dan Kinerja Perusahaan.
Jurnal Manajemen dan Bisnis. Volume 14 No 2.

Zamzam, F., \& Aravik, H. (2016). Manajemen SDM Berbasis Syariah, Bogor: CV. RWTC Success 